\title{
Constructing a greenhouse gas emissions inventory using energy balances: the case of South Africa for 1998
}

\author{
JN Blignaut \\ MR Chitiga-Mabugu \\ Both of the Department of Economics, University of Pretoria, Pretoria, South Africa
}

RM Mabugu

Centre for Environmental Economics and Policy in Africa (CEEPA), University of Pretoria, Pretoria, South Africa

\begin{abstract}
This paper discusses the procedures and results of constructing a greenhouse gas (GHG) emissions inventory for South Africa, using the official national energy balance for 1998. In doing so, the paper offers a snapshot of the South African energy supply and demand profile and encompassing greenhouse gas emissions profiles, disaggregated into 40 economic sectors, for the reference year. For convenience, energy supply and use are reported in both native units and terra joule (TJ), while emissions are expressed in carbon dioxide equivalents and reported in giga-gram (Gg). While carbon dioxide makes an overwhelming contribution to global anthropogenic GHG emissions, the inclusion of methane and nitrous oxide offers considerable richness to the analysis of climate change policies. Applying the energy balances, it was possible to compile a comprehensive emissions inventory using a consistent methodology across all sectors of the economy. The inventory allows the economic analyst to model various economic policies either with fuel as an input to production, or the consumption of fuel or the emissions generated during combustion, as a base of the analysis. The dominant role of coal as a source of energy, with a total primary energy supply (TPES) of 3.3 million TJ or 70 per cent of the total TPES, is clearly shown. Emissions from coal combustion (263 $783 \mathrm{Gg}$ of carbon dioxide equivalents or 74.7 per cent of total emissions) are henceforth the largest contributor to total emissions, estimated to be $352932 \mathrm{Gg}$ carbon dioxide equivalents.

Keywords: energy balances, greenhouse gas emissions, greenhouse gas inventory, emission factors, economic sectors, IPCC, South Africa
\end{abstract}

\section{Introduction}

Developing countries, also known as non-Annex I parties according to the Kyoto Protocol, have 'common but differentiated' responsibilities as outlined in Article $4(\mathrm{a}-\mathrm{j})$ of the United Nations Framework Convention on Climate Change (UNFCCC) (UNFCCC, 1999). This means that neither are they obligated to reduce greenhouse gas (GHG) emissions, nor will they be required to do so during the first commitment period (2008-2012) of the Kyoto Protocol. At the same time, increasing pressure is placed on developing countries to share the burden of GHG reduction. This might result in non-Annex I countries having emission reduction commitments during the second commitment period after 2012. Part of the reluctance of developing countries to participate in global climate change initiatives stems from a lack of empirical research to inform policy. The lack of solid empirical work can partially be explained by the lack of official greenhouse gas emissions inventories that are both on time and reliable.

The question that now arises is whether it is possible to use the national energy balance, published annually by national authorities in charge of energy statistics, as a source of information to calculate an emissions inventory that could be linked to economic sectors to be used in economic analysis and modelling. This is the question addressed in this study, focusing on South Africa. To address this issue, the next section provides background information regarding existing GHG emissions data and motivates for the compilation of a comprehensive and consistent methodology that could be used timeously and repeatedly at low cost, but with a high degree of accuracy, to compile an unofficial greenhouse gas emissions inventory. Thereafter, the methodology followed to calculate the new emis- 
sions inventory is discussed, followed by the study results and a discussion thereof. A conclusion completes the paper.

\section{Background}

Despite the importance of data on greenhouse gas (GHG) emissions, no official GHG emissions inventory beyond 1994 exists in South Africa. The summary of the emissions inventory is provided in Table 1. From this it is clear that carbon dioxide $\left(\mathrm{CO}_{2}\right)$ is by far the largest greenhouse gas being emitted, though the global warming potential of the other two gasses, methane $\left(\mathrm{CH}_{4}\right)$ and nitrous oxide $\left(\mathrm{N}_{2} \mathrm{O}\right)$, is significantly higher. It is also clear that the energy sector is the main emitter of GHG emissions. This is mainly the result of the combustion of fossil fuels; especially coal. Notwithstanding the fact that the information is rather dated, the other concern regarding this inventory is that it does not indicate neatly the source of fuel, the fuel type, the sector combusting the fuel or the purpose for fuel com- bustion. This is the type of analysis, or data mapping, required doing economic analysis when considering the economic impact of various policies aimed at mitigating the country's GHG emissions. This analysis could include the use of economywide modelling techniques such as Computable General Equilibrium (CGE) Models, Social Accounting Matrix (SAM) Impact Models and InputOutput Models.

As far as the current South African literature on emission data is concerned, there are a number of sector specific studies that offer sector specific emissions data. These include studies focusing on the transport sector (Gaffen et al., 2000 and Freeman et al., 2000), the electricity sector (Spalding-Fecher et al., 2000), the liquid fuel sector (Lloyd et al., 2000) and the mining sector (Clement and Foster, 2000). Other studies focusing on the manufacturing sector include those by Visser et al. (2000), Trikam (2002), Blignaut and King (2002) and Blignaut and Zunckel (2004).

Table 1: Official GHG emissions inventory Source: RSA (2000)

\begin{tabular}{|c|c|c|c|c|c|c|}
\hline & \multicolumn{2}{|c|}{$\mathrm{CO}_{2}$} & \multicolumn{2}{|c|}{$\mathrm{CH}_{4}$} & \multicolumn{2}{|c|}{$\mathrm{N}_{2} \mathrm{O}$} \\
\hline & 1990 & 1994 & 1990 & 1994 & 1990 & 1994 \\
\hline Energy & 256764 & 287851 & 349 & 376 & 5 & 6 \\
\hline energy industries & 156373 & 167817 & 1 & 0 & 3 & 3 \\
\hline industry & 47026 & 53186 & 6 & 6 & 1 & 1 \\
\hline transport & 30779 & 42717 & 9 & 11 & 1 & 2 \\
\hline commercial & 11844 & 780 & 1 & 0 & 0 & 0 \\
\hline residential & 7542 & 7397 & 9 & 1 & 0 & 0 \\
\hline agriculture & 3200 & 15954 & 0 & 31 & 0 & 1 \\
\hline fugitive emissions & & & 324 & 327 & & \\
\hline Industrial processes & 31190 & 30010 & 3 & $\mathbf{1}$ & 5 & 6 \\
\hline mineral products & 5478 & 5331 & & & & \\
\hline chemical industry & 3936 & 3856 & 3 & 1 & 5 & 6 \\
\hline metal production & 21776 & 20823 & & & & \\
\hline Agriculture & & & 1014 & 937 & 62 & 51 \\
\hline enteric fermation & & & 917 & 844 & & \\
\hline manure management & & & 83 & 78 & 1 & 0 \\
\hline agricultural soils & & & & & 60 & 50 \\
\hline savanna burning & & & 13 & 13 & 1 & 1 \\
\hline agricultural residues burning & & & 2 & 2 & 0 & 0 \\
\hline Land use change and forestry & -16982 & -18616 & & & & \\
\hline changes in biomass & -13641 & -10886 & & & & \\
\hline soil removals & -3341 & -7730 & & & & \\
\hline Waste & & & 666 & 743 & 2 & 3 \\
\hline solid waste on land & & & 647 & 722 & & \\
\hline waste water handling & & & 19 & 21 & 2 & 3 \\
\hline International bunkers & 7195 & 10220 & & & & \\
\hline
\end{tabular}


All of these have in common the fact that they needed an emissions inventory for the respective economic sectors, and had to rely on various different methodologies and sources of data to compile an inventory for their specific sectors of interest. This has the advantage that, at that time, invaluable information was made available regarding the specific sector. The disadvantage, however, is that, since these studies are based on different methodologies, base years and sources, they are not comparable. Also, trying to get a comprehensive picture of the emissions profile of the country based on such a variety of studies covering a variety of sectors is very cumbersome and difficult, and could ultimately lead to costly mistakes. Howells and Solomon (2000) used such a sector-specific method in developing a greenhouse gas emissions inventory with 1994 as the reference year. They have gone into great length to analyse the energy sector and calculate sector specific emissions based on a common methodology. The problem, however, is that the sector demarcation does not correspond strictly with that of the standard industrial classification used by economic analysts. Furthermore, the most recent comprehensive economy-wide inventory is for 1998, and, lastly, the need exists to get a methodology to estimate a greenhouse gas emissions inventory much more regularly and with a degree of coherent simplicity that makes it possible for a large number of people to estimate a greenhouse gas inventory.

The current state of affairs regarding greenhouse gas emissions inventories leaves the economy-wide economic analyst in a precarious position: either use the dated but comprehensive national GHG inventory and adapt that to conform to the international industrial sector classification used in compiling an input-output or social accounting matrix, or use the more recent but fragmented sectoral studies to construct a new inventory. Neither solution is optimal, hence the need for a comprehensive and internationally consistent GHG emissions inventory. Foster (1998) attempted this. Although he made considerable use of primary data sources, his approach, however, did not allow the mapping of emission by fuel and sector in a way that is inherently consistent across sectors and fuels. This is what is attempted here through this study. It was also the express purpose to develop a methodology that could be repeated regularly, and by various people. This methodology will subsequently be discussed.

\section{Methodology 3.1 General}

In the light of the difficulties mentioned above, a GHG emissions inventory has been compiled using the national energy balance as published by the
Department of Minerals and Energy (DME, 2000). These balances are compiled on an annual basis and provide data on the production, consumption, exports, imports and stock changes of black coal, brown coal, briquettes, coke, crude oil, a variety of petroleum products, natural gas, and electricity production. The published tables reconcile national supply figures for each fuel, calculated from indigenous production, exports and imports, with the detailed sector-by-sector energy consumption figures. Reconciliation is achieved in both native units (i.e. tons, MWh and kl) and standardised energy units (i.e. tons of oil equivalent, and TJ).

This information has been used to calculate the $\mathrm{CO}_{2}, \mathrm{CH}_{4}$ and $\mathrm{N}_{2} \mathrm{O}$ emissions per sector, per fuel group for 1998 using various emission factors (see discussion below). 1998 was selected as a reference year since this corresponds to the latest available official South African Social Accounting Matrix (SAM), but the same methodology could easily be applied to any energy balance. This methodology allowed the mapping of emissions by fuel and sector in a way that is inherently consistent across sectors and fuels and amenable to the structure of the South African SAM (see Table 2 for the sectoral cross tabulation). This implies that economic policy analysis through integrated environmental-economic modelling is possible. Not only the emissions by fuel and sector, but also the energy consumption by fuel and sector in either a standardised unit (e.g. $\mathrm{TJ}$ ) or native units could be mapped.

The fossil fuels combusting and contributing to GHG emissions included in the inventory comprise coal, oil and natural gas. Most of the emissions embodied in oil are attributed to the consumption of petroleum products, because oil is largely transformed into these products. Only the emissions by oil refineries during the transformation process are attributed to oil. Similarly, to avoid double counting, only the generation of electricity, and not the consumption thereof, contributes to emissions. Currently, the inventory does not account for noncombustion GHG emissions. Non-combustion emissions of GHG comprise fugitive emissions from oil and natural gas systems, and emissions from industrial processes such as aluminium production and cement manufacturing. Neither does the inventory include emissions from burning savannas and agricultural residues.

In the inventory, emissions of each GHG are expressed in carbon dioxide equivalents, based on the global warming potentials that measure the relative radiative forcing of different GHG over a specific period. These global warming potentials over a century time horizon are 1,21 and 310 for carbon dioxide, methane and nitrous oxide respectively, as recommended by the International Panel on Climate Change (IPCC, 1996). 
Table 2: Sectoral cross tabulation: SAM and national energy balance Source: Own analysis

\begin{tabular}{ll}
\hline Energy balance sector & \multicolumn{1}{c}{ Treatment in the SAM } \\
\hline $\begin{array}{l}\text { Iron and steel } \\
\text { Chemical and petrochemical } \\
\text { fuel type by each sector }\end{array}$ & Split into chemical and petroleum products according to the use of each \\
\hline Non-ferrous metals & Nonferrous metals \\
\hline Non-metallic minerals & Non-metallic minerals \\
\hline Transport equipment & Transport equipment \\
\hline Machinery & Machinery \\
\hline Mining and quarrying & $\begin{array}{l}\text { Split into gold, coal, crude oil and gas and other mining according to the } \\
\text { use of each fuel type by each sub-sector }\end{array}$ \\
\hline Food and tobacco & Food \\
\hline Paper pulp and print & Paper, pulp and wood \\
\hline Wood and wood products & Paper, pulp and wood \\
\hline Construction & Construction \\
\hline Textile and leather & Textile \\
\hline Non-specified (industry) & Other manufactures \\
\hline Transport sector & Transport services \\
\hline Agriculture & $\begin{array}{l}\text { Split into irrigated and dry field, irrigated and dry horticulture, livestock, } \\
\text { forestry and other agriculture according to the use of each fuel type by } \\
\text { each sub-sector }\end{array}$ \\
\hline Commerce andpublic services & $\begin{array}{l}\text { Split into the various service sectors according to the use of each fuel } \\
\text { type by each sub-sector }\end{array}$ \\
\hline Residential & Allocated to households \\
\hline Non-specified (Other) & Other service activities \\
\hline
\end{tabular}

\subsection{Carbon dioxide emissions}

\section{Coal-based $\mathrm{CO}_{2}$-emissions}

The carbon contained in fossil fuel oxidises and transforms into mainly $\mathrm{CO}_{2}$ during combustion. Currently there is no technology for the successful mitigation of $\mathrm{CO}_{2}$ emissions. The emission of $\mathrm{CO}_{2}$ depends on the quantity and type of the fuel used and follows the laws of material balance and thermodynamics. The amount of $\mathrm{CO}_{2}$ emitted can be calculated using two different approaches, namely the reference and the sectoral approaches. Using the reference approach, the input data are production, import, export, international bunkers and stock change for primary and secondary fuel. The more detailed sectoral approach implies the calculation of emissions using fuel consumption in different energy sub-sectors. The difference between the reference and the sectoral approaches should be relatively small. This study applies the sectoral approach for calculating the carbon dioxide emissions from the combustion of fossil fuels (see IEA 2001 for details), with some modification.

Emissions of $\mathrm{CO}_{2}$ from coal combustion were calculated by multiplying the quantity of coal consumed in each sector by an effective emission fac- tor for coal in that sector. To compute $\mathrm{CO}_{2}$ emission factors for coal combustion, the coal consumption and resulting $\mathrm{CO}_{2}$ emissions for 2000 reported in Blignaut and King (2002) were used and it was assumed that these factors were the relevant ones for 1998. The implied emission factors are shown in Table 3. These emission factors, especially that of electricity generation, is lower than the listed IPCC default factor of $94.6 \mathrm{t} \mathrm{CO}_{2} / \mathrm{TJ}$, but is based on published data for both emissions and coal consumption. A possible explanation for the difference might lie in the fact that the conversion of coal consumption to TJ is based on Pinheiro et al.'s (1997) gross calorific value of coal used for electricity, which is given as $20,37 \mathrm{MJ} / \mathrm{kg}$.

\section{Non-coal-based $\mathrm{CO}_{2}$-emissions}

Carbon dioxide emissions from non-coal fossil fuel sources have been calculated in a similar way to that of coal, namely by multiplying the fuel consumption in each sector by the respective emission factor. The basis for the estimate is the fuel used in different energy sectors, grouped into the fossil fuels categories according to its aggregate condition, namely crude oil, petrol, diesel, other petroleum, 
Table 3: Coal emission factors

Source: Own calculations based on Blignaut and King (2002) as reported in Blignaut and Zunckel (2004)

\begin{tabular}{lc}
\hline \multicolumn{1}{c}{ Sector } & $\begin{array}{c}\text { Emission factor } \\
\text { t } \mathrm{CO}_{2} / \mathrm{TJ}\end{array}$ \\
\hline Agriculture & 76.43 \\
\hline Mining and quarrying & 76.13 \\
\hline Iron and steel & 77.15 \\
\hline Non-metallic & 76.22 \\
\hline $\begin{array}{l}\text { Chemical and petrochemical } \\
\text { industries }\end{array}$ & 53.61 \\
\hline Auto-producer electricity plant & 76.50 \\
\hline Public electricity plant & 85.74 \\
\hline Non specified transport & 76.50 \\
\hline $\begin{array}{l}\text { Commerce and public services, } \\
\text { residential, non-specified other }\end{array}$ & 76.99 \\
\hline
\end{tabular}

gas and renewables. Data about quantities of the fuel used are taken from the energy balance in $\mathrm{TJ}$ (DME, 2000).

The carbon content factors used for calculations are distinguished by fuel source and obtained from IPCC guidelines on emission factors. The factors applied to the different fuel categories are shown in Table 4.

Table 4: Carbon emission factors used for other energy sources Source: IPCC 1995

\begin{tabular}{|c|c|}
\hline Liquid fossil & $\begin{array}{l}\text { 20.0t C/TJ Crude oil } \\
\text { 18.9t C/TJ Petrol } \\
\text { 20.2t C/TJ Diesel } \\
\text { 19.5t C/TJ Jet kerosene } \\
\text { 19.6t C/TJ Other kerosene } \\
\text { 20.0t C/TJ Shale oil } \\
\text { 21.1t C/TJ Residual fuel oil } \\
\text { 17.2t C/TJ LPG } \\
\text { 16.8t C/TJ Ethane } \\
\text { 20t C/TJ Naphta } \\
\text { 22.0t C/TJ Bitumen } \\
\text { 20.0t C/TJ Lubricants } \\
\text { 27.5t C/TJ Petroleum coke } \\
\text { 20.0t C/TJ Refinery feedstocks } \\
\text { 18.2t C/TJ Refinery gas } \\
\text { 20.0t C/TJ Other oil }\end{array}$ \\
\hline Gaseous fossil & 15.3t C/TJ Natural gas (dry) \\
\hline Biomass & $\begin{array}{l}\text { 29.9t C/TJ Solid biomass } \\
\text { 20.0t C/TJ Liquid biomass } \\
\text { 30.6t C/TJ Gas biomass }\end{array}$ \\
\hline
\end{tabular}

General

In short, the carbon dioxide emission factors are calculated by multiplying the carbon emission fac- tors (adjusted for oxidation) of a particular fuel by $3.6667 \mathrm{~kg} \mathrm{CO} 2$ per kilogram of carbon, and multiplying that product by the energy amount of that fuel consumed, and the steps followed are depicted by the following equation:

$$
\mathrm{CO}_{2}=\sum\left[A C T I V I T Y \times E F \times \frac{44}{12}\right]
$$

where

$\mathrm{CO}_{2}=$ carbon dioxide emissions from fossil fuel combustion (in $\mathrm{Gg}$ )

ACTIVITY = fuel consumption converted to $\mathrm{TJ}$

$\mathrm{EF} \quad=$ emission factor, equal to carbon coefficient multiplied by oxidation factor, expressed as $\mathrm{t} / \mathrm{TJ}$

$44 / 12=$ molecular weight ratio of $\mathrm{CO}_{2}$ to carbon.

Because not all carbon is oxidized, a relevant oxidation factor is applied. The oxidation ${ }^{1}$ factors used are shown in Table 5.

Table 5: Oxidation factors for $\mathbf{C O}_{2}$ Source: IPCC (1995, Vol 3)

\begin{tabular}{lcc}
\hline Fuel & Utilisation category & Oxidation factor \\
\hline Coal & Electricity generation & $99 \%^{\mathrm{a}}$ \\
\hline & Manufacturing industry & $98 \%^{\mathrm{b}}$ \\
\hline \multicolumn{3}{c}{$\begin{array}{c}\text { Commercial, residential } \\
\text { and other }\end{array}$} \\
\hline Oil & All & $95 \%^{\mathrm{a}}$ \\
\hline Gas & All & $99 \%^{\mathrm{a}}$ \\
\hline
\end{tabular}

\section{Notes}

a. default value

b. default value for 'best practice'. Depending on maintenance procedures and efficiency, IPCC proposes a range of $90-98 \%$ for stoker fired industrial boilers.

\subsection{Non-carbon dioxide emissions}

As discussed above, the sources of methane and nitrous oxide emissions covered include combustion sources only, and computed using the following approach:

$$
G A S=A C T I V I T Y * E F
$$

where

Activity $=$ fuel consumption converted to $\mathrm{TJ}$

$\mathrm{EF} \quad=$ emission factor, expressed as $\mathrm{kg} / \mathrm{TJ}$

\section{Methane}

There are a number of ways suggested in the literature to account for the emission of methane. There are emission factors from the IPCC IGES database, IPCC default emission factors or even using the average from a cluster of countries. This study used 
the IPCC default guidelines (see Table 6) to be consistent with the methodology used for carbon. While it generally desirable to use country-specific emission factors, data limitations have dictated the use of this methodology.

Table 6: Emission factors for $\mathrm{CH}_{4}(\mathrm{~kg} / \mathrm{TJ})$ Source: IPCC (1996)

\begin{tabular}{lc}
\hline Sector & $\begin{array}{c}\text { Emission factor } \\
\mathrm{kg} \text { CH4/TJ }\end{array}$ \\
\hline Energy industries & \\
$\quad$ Liquid fuels & 3 \\
Solid fuels & 1 \\
Gaseous fuels & 1 \\
Waste & 30 \\
\hline Manufacturing industries & \\
$\quad$ Liquid fuels & 2 \\
$\quad$ Solid fuels & 10 \\
Gaseous fuels & 5 \\
Waste & 30 \\
\hline Other sectors & \\
Liquid fuels & 10 \\
Solid fuels & 300 \\
Gaseous fuels & 5 \\
Biomass and waste & 300 \\
\hline
\end{tabular}

\section{Nitrous oxide}

For nitrous oxide from the transport sector, the IPCC default emission factor values have been used. The IPCC gives a constant emission factor of $0.6 \mathrm{~kg} / \mathrm{TJ}$ for both petrol and diesel, but a footnote to the gasoline emission factor states that when there are a significant number of cars with threeway catalysts in the country, road transport emission factors should be increased accordingly. To take into account expected increases in emissions over time as the use of catalysts increases, one has to consider changes in technologies. It has been assumed that, while in 1990 all cars in South Africa were non-catalyst-controlled (with an emission factor of $1.4 \mathrm{~kg} / \mathrm{TJ}$ ), in 1998 all cars were equipped with three-way catalysts (with an emission factor of $7.3 \mathrm{~kg} / \mathrm{TJ}$ ). The emission factor for electricity is computed from actual emission figures reported in Eskom (2000) and works out to $2.86 \mathrm{~kg} \mathrm{~N}_{2} \mathrm{O} / \mathrm{TJ}$. The emission parameters used are summarised in Table 7.

\section{Results of the energy and greenhouse gas emission inventory for South Africa (1998)}

Total primary energy supply (TPES) comprises indigenous production plus imports, less exports, less international marine bunkers, and less stock changes. Table 8 illustrates the main sources of energy in South Africa in 1998 in TJ. The dominant
Table 7: Emission parameters for $\mathrm{N}_{2} \mathrm{O}$ emissions

Sources: IPCC (1996) and Eskom (2000)

\begin{tabular}{lc}
\hline Fuel & Emission factor \\
\hline LPG & $0.1 \mathrm{~kg} \mathrm{~N}_{2} \mathrm{O} / \mathrm{TJ}$ \\
\hline Natural gas & $0.1 \mathrm{~kg} \mathrm{~N}_{2} \mathrm{O} / \mathrm{TJ}$ \\
\hline Electricity & $2.86 \mathrm{~kg} \mathrm{~N}_{2} \mathrm{O} / \mathrm{TJ}$ \\
\hline Diesel & $0.6 \mathrm{~kg} \mathrm{~N} 2 \mathrm{O} / \mathrm{TJ}$ \\
\hline Petrol & $7.3 \mathrm{~kg} \mathrm{~N}_{2} \mathrm{O} / \mathrm{TJ}$ \\
\hline
\end{tabular}

role of coal in the economy is evident from the Table, contributing more than 70 per cent of the country's energy needs. Approximately 25 per cent of the country's energy needs are met by crude oil, while natural gas, nuclear, renewable energy and biomass combined contribute a total of less than 10 per cent. Also indicated in the table is that petroleum and crude oil are mainly imported, while the other fuels originate mainly from domestic sources.

After adjusting for statistical differences and energy used, or being made available during the energy transformation processes (i.e. the conversion of coal to electricity through coal-fired power stations and crude oil to petroleum products through oil refineries), the energy available for final consumption is derived (see Table 8). Figure 1 indicates the share of final demand by the fuel used in South Africa during 1998. Electricity accounted for approximately 24 per cent of total final demand energy, while petroleum met 33 per cent of final demand energy needs. Coal accounted for 31 per cent of final demand, and renewables and gas for 11 per cent.

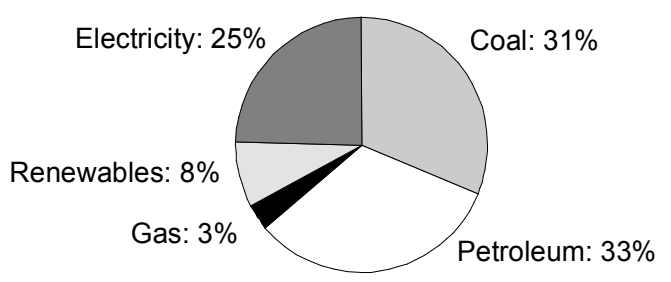

\section{Figure 1: Share of final demand for energy by fuel type in 1998 by percentage Source: Table 8}

Table 9 shows the final demand for energy in $\mathrm{TJ}$ and in native units, where applicable, for 40 sectors. Taken as an aggregate, one sees that the industrial sector is the largest consumer of total energy, accounting for 44.2 per cent of all energy consumed in South Africa. Services account for 26.2 per cent of all energy consumed, while agriculture demands 5 per cent, mining 8 per cent and the residential sector demands 16 per cent. Taken individually, the trade sector is the largest consumer of 
Table 8: South Africa's total primary energy supply (TJ) Source: DME (2000) and own calculations

\begin{tabular}{|c|c|c|c|c|c|c|c|c|c|}
\hline & Coal & Crude Oil & Petroleum & Gas & Nuclear & Hydro & Renewables & Electricity & Total \\
\hline Indigenous production & 5278319 & 293876 & - & 53983 & 148375 & 5742 & 237400 & - & 6017694 \\
\hline Imports & 36147 & 897696 & 40948 & - & - & - & - & 8550 & 983342 \\
\hline Intl. marine bunkers & - & - & -122341 & - & - & - & - & - & -122341 \\
\hline Stock changes & -329875 & - & - & - & - & - & - & - & -329875 \\
\hline TPES \% & 70.4 & 25.1 & -4.9 & 1.2 & 3.2 & 0.1 & 5.1 & -0.1 & 100 \\
\hline Energy transformation $^{1}$ & -2783868 & -1162648 & 998318 & -22791 & -148375 & -5742 & -47000 & 622322 & -2549784 \\
\hline Statistical difference $^{2}$ & 241939 & 0 & -24761 & 43651 & 0 & 0 & 0 & -43406 & 217423 \\
\hline Total final consumption & 726269 & 0 & 744591 & 74843 & 0 & 0 & 190400 & 571151 & 2307253 \\
\hline
\end{tabular}

\section{Notes:}

1. A portion of the TPES is transformed into other forms of energy, e.g. coal and crude oil to electricity and petroleum products respectively. Energy used during this transformation process is therefore not part of the final consumption component. Henceforth, the fact that petroleum and electricity are indicated as the recipient sectors by a positive value and the source sectors (coal, crude oil, nuclear, hydro, gas and renewables) by a negative sign. During the transformation process, there is a net energy loss of 2.55 million TJ as indicated in the last column.

2. The difference between the TPES plus energy transformation and the total final consumption.

energy, consuming 20.6 per cent of all energy, followed by the residential sector with 16.3 per cent. Iron and steel, petroleum products and other metal products largely account for industrial consumption.

From the same table it is evident that the residential sector, gold mining, iron and steel, other metal products and non-ferrous metals consume the lion's share of electricity. In contrast, agriculture is a relatively small consumer of electricity. The petrochemical industry, iron and steel and other metal products dominate the demand for coal. The rest of the sectors are small consumers spread across the economy. The trade sector demands 61 per cent of petroleum products. Agriculture is also a fairly important consumer of petroleum products. Gas is mainly consumed by the iron and steel industry (almost 79 per cent). The final demand for renewables is exclusively accounted for by the residential sector.

Table 10 shows emissions in carbon dioxide equivalents for 1998 by sector and source of fuel. Of the total amount of $\mathrm{CO}_{2}$ equivalent emissions of $352932 \mathrm{Gg}$, coal dominates the emissions as a source, contributing $263783 \mathrm{Gg}$ of $\mathrm{CO}_{2}$-equivalent or 74.7 per cent of the total emissions, followed by petroleum products with $53744 \mathrm{Gg}$ or 15.2 per cent, then renewables with 6.6 per cent and crude oil and gas with 3.4 per cent. Emissions that occur during energy transformation and the final consumption of the various fuel sources are taken into consideration. To avoid double counting, electricity is not viewed as a fuel source in this respect since emissions during the final consumption of electricity are considered to be zero. Electricity is viewed as a sector that consumes fuel.

Electricity generation (65.9 per cent) and petroleum refineries (20.4 per cent) dominate emissions from the combustion of coal, as indicated in Table 10 as well. These two sectors therefore contribute to more than 86 per cent of total emissions from the combustion of coal. Emissions from the combustion of petroleum are dominated by the trade sector (60.1 per cent), more specifically the retail sales of petroleum. Emissions from crude oil and gas are mainly concentrated in the petroleum refineries (60.1 per cent) and iron and steel industries (27.2 per cent). The former mainly converts crude oil to petroleum and the latter uses gas. It should be noted that emissions are allocated to the sector at the point of combustion. Therefore, the emissions allocated to the petroleum refineries are emissions that occur during the refinery process. The embedded carbon in the fuel is only emitted during the combustion of the fuel, mainly through motor vehicles. Private petroleum sales are allocated to the retail trade sector. This distinction is essential to ensure that there is no double counting. Emissions from renewable sources are only concentrated in the electricity and residential sectors. With regard to the former, it reflects the use of renewable materials for the generation of electricity for own consumption by industries such as in the paper and pulp and automotive industries. In total, electricity generation, petroleum refineries and the retail trade sectors contribute to 77.1 per cent of emissions. 
Table 9: Final demand for energy by sector and fuel in TJ, native unit and share percentage Source: Own calculations based on DME (2000)

\begin{tabular}{|c|c|c|c|c|c|c|}
\hline & \multicolumn{3}{|c|}{ Coal } & \multicolumn{3}{|c|}{ Petroleum } \\
\hline & $T J$ & $T$ & $\%$ & $T J$ & $k l$ & $\%$ \\
\hline Irrigated field & 1124 & 41621 & 0.2 & 11239 & 307137 & 1.5 \\
\hline Dry field & 3772 & 139719 & 0.5 & 37742 & 1031404 & 4.9 \\
\hline Irrigated horticulture & 1 & 20 & 0 & 14425 & 394191 & 1.9 \\
\hline Dry horticulture & 1 & 21 & 0 & 3885 & 106161 & 0.5 \\
\hline Livestock & 1 & 19 & 0 & 17760 & 485326 & 2.3 \\
\hline Forestry & 0 & 13 & 0 & 0 & 0 & 0 \\
\hline Other agriculture & 59 & 2173 & 0 & 9099 & 248646 & 1.2 \\
\hline Coal & 284 & 10526 & 0 & 12929 & 354158 & 1.7 \\
\hline Gold & 6233 & 230856 & 0.9 & 9257 & 253574 & 1.2 \\
\hline Crude, pet. \& gas & 0 & 2 & 0 & 3766 & 103174 & 0.5 \\
\hline Other mining & 34466 & 1276516 & 4.7 & 14897 & 408066 & 1.9 \\
\hline Food & 0 & 0 & 0 & 0 & 0 & 0 \\
\hline Textiles & 0 & 0 & 0 & 0 & 0 & 0 \\
\hline Footwear & 0 & 0 & 0 & 399 & 10783 & 0.1 \\
\hline Other chemical \& rubber & 8585 & 317966 & 1.2 & 0 & 0 & 0 \\
\hline Petroleum refineries & 253359 & 9383664 & 34.8 & 0 & 0 & 0 \\
\hline Othr non-metal. minerals & 33990 & 1258880 & 4.7 & 0 & 0 & 0 \\
\hline Iron \& steel & 181673 & 6767902 & 25.1 & 0 & 0 & 0 \\
\hline Non-ferrous metals & 0 & 0 & 0 & 0 & 0 & 0 \\
\hline Other metal products & 89253 & 3303538 & 12.3 & 16289 & 439999 & 2.1 \\
\hline Other machinery & 0 & 0 & 0 & 0 & 0 & 0 \\
\hline Electrical machinery & 0 & 0 & 0 & 14856 & 401284 & 1.9 \\
\hline Radio & 0 & 0 & 0 & 2016 & 54466 & 0.3 \\
\hline Transport equipment & 0 & 0 & 0 & 0 & 0 & 0 \\
\hline Wood, pulp \& paper & 0 & 0 & 0 & 0 & 0 & 0 \\
\hline Other manufacturing & 37179 & 1376112 & 5.1 & 10045 & 271324 & 1.3 \\
\hline Electricity & 0 & 0 & 0 & 0 & 0 & 0 \\
\hline Water & 10525 & 389798 & 1.4 & 21 & 573 & 0 \\
\hline Construction & 10 & 387 & 0 & 21647 & 590896 & 2.8 \\
\hline Trade & 486 & 18013 & 0.1 & 449352 & 12791600 & 61.1 \\
\hline Hotels & 876 & 32442 & 0.1 & 24 & 648 & 0 \\
\hline Transport services & 1396 & 51707 & 0.2 & 52632 & 1494073 & 7.1 \\
\hline Communication & 0 & 0 & 0 & 246 & 6638 & 0 \\
\hline Financial institutions & 0 & 0 & 0 & 108 & 2901 & 0 \\
\hline Real estate & 0 & 0 & 0 & 176 & 4749 & 0 \\
\hline Business activities & 0 & 0 & 0 & 121 & 3273 & 0 \\
\hline General government & 7493 & 277537 & 1 & 14355 & 408067 & 1.9 \\
\hline Health sector & 4612 & 170807 & 0.6 & 215 & 5794 & 0 \\
\hline Other service activities & 409 & 15142 & 0.1 & 56 & 1512 & 0 \\
\hline Residential & 50483 & 1869744 & 6.9 & 27033 & 766197 & 3.7 \\
\hline Total & 726269 & 26935123 & 100 & 744591 & 20946615 & 100 \\
\hline
\end{tabular}




\begin{tabular}{|c|c|c|c|c|c|c|c|c|}
\hline \multicolumn{2}{|c|}{ Gas } & \multicolumn{2}{|c|}{ Renewables } & \multicolumn{3}{|c|}{ Electricity } & \multicolumn{2}{|c|}{ Total } \\
\hline$T J$ & $\%$ & $T J$ & $\%$ & $T J$ & $M W h$ & $\%$ & $T J$ & $\%$ \\
\hline 0 & 0 & 0 & 0 & 1973 & 547974 & 0.3 & 14336 & 0.6 \\
\hline 0 & 0 & 0 & 0 & 6625 & 1840164 & 1.2 & 48139 & 2.1 \\
\hline 0 & 0 & 0 & 0 & 3574 & 992796 & 0.6 & 17999 & 0.8 \\
\hline 0 & 0 & 0 & 0 & 963 & 267375 & 0.2 & 4848 & 0.2 \\
\hline 0 & 0 & 0 & 0 & 4451 & 1236380 & 0.8 & 22211 & 1 \\
\hline 0 & 0 & 0 & 0 & 771 & 214045 & 0.1 & 771 & 0 \\
\hline 0 & 0 & 0 & 0 & 3049 & 846807 & 0.5 & 12206 & 0.5 \\
\hline 56 & 0.1 & 0 & 0 & 11029 & 3063574 & 1.9 & 24298 & 1.1 \\
\hline 123 & 0.2 & 0 & 0 & 69117 & 19199242 & 12.1 & 84731 & 3.7 \\
\hline 193 & 0.3 & 0 & 0 & 25 & 7057 & 0 & 3985 & 0.2 \\
\hline 126 & 0.2 & 0 & 0 & 25550 & 7097101 & 4.5 & 75039 & 3.3 \\
\hline 1,154 & 1.5 & 0 & 0 & 2081 & 578116 & 0.4 & 3235 & 0.1 \\
\hline 18 & 0 & 0 & 0 & 1342 & 372749 & 0.2 & 1360 & 0.1 \\
\hline 0 & 0 & 0 & 0 & 1735 & 482002 & 0.3 & 2134 & 0.1 \\
\hline 313 & 0.4 & 0 & 0 & 5077 & 1410337 & 0.9 & 13976 & 0.6 \\
\hline 2,738 & 3.7 & 0 & 0 & 4390 & 1219413 & 0.8 & 260487 & 11.3 \\
\hline 6,314 & 8.4 & 0 & 0 & 4159 & 1155161 & 0.7 & 44462 & 1.9 \\
\hline 58980 & 78.8 & 0 & 0 & 67914 & 18865014 & 11.9 & 308567 & 13.4 \\
\hline 957 & 1.3 & 0 & 0 & 53170 & 14769314 & 9.3 & 54127 & 2.3 \\
\hline 0 & 0 & 0 & 0 & 79970 & 22213943 & 14 & 185512 & 8 \\
\hline 604 & 0.8 & 0 & 0 & 133 & 36875 & 0 & 737 & 0 \\
\hline 0 & 0 & 0 & 0 & 18884 & 5245503 & 3.3 & 33740 & 1.5 \\
\hline 0 & 0 & 0 & 0 & 4790 & 1330642 & 0.8 & 6807 & 0.3 \\
\hline 106 & 0.1 & 0 & 0 & 55 & 15147 & 0 & 160 & 0 \\
\hline 541 & 0.7 & 0 & 0 & 5986 & 1662673 & 1 & 6526 & 0.3 \\
\hline 2501 & 3.3 & 0 & 0 & 11831 & 3286262 & 2.1 & 61555 & 2.7 \\
\hline 0 & 0 & 0 & 0 & 0 & 0 & 0 & 0 & 0 \\
\hline 0 & 0 & 0 & 0 & 3387 & 940745 & 0.6 & 13932 & 0.6 \\
\hline 0 & 0 & 0 & 0 & 350 & 97290 & 0.1 & 22008 & 1 \\
\hline 10 & 0 & 0 & 0 & 25775 & 7159615 & 4.5 & 475623 & 20.6 \\
\hline 0 & 0 & 0 & 0 & 5271 & 1464032 & 0.9 & 6170 & 0.3 \\
\hline 77 & 0.1 & 0 & 0 & 12476 & 3465541 & 2.2 & 66581 & 2.9 \\
\hline 0 & 0 & 0 & 0 & 5786 & 1607124 & 1 & 6032 & 0.3 \\
\hline 0 & 0 & 0 & 0 & 4760 & 1322227 & 0.8 & 4868 & 0.2 \\
\hline 11 & 0 & 0 & 0 & 3881 & 1078060 & 0.7 & 4069 & 0.2 \\
\hline 0 & 0 & 0 & 0 & 466 & 129568 & 0.1 & 588 & 0 \\
\hline 19 & 0 & 0 & 0 & 3595 & 998640 & 0.6 & 25463 & 1.1 \\
\hline 0 & 0 & 0 & 0 & 2407 & 668637 & 0.4 & 7234 & 0.3 \\
\hline 0 & 0 & 0 & 0 & 5770 & 1602712 & 1 & 6235 & 0.3 \\
\hline 0 & 0 & 190400 & 100 & 108587 & 30163089 & 19 & 376504 & 16.3 \\
\hline 74843 & 100 & 190400 & 100 & 571151 & 158652942 & 100 & 2307253 & 100 \\
\hline
\end{tabular}


Table 10: Emissions by sector and source: Gg CO2-equivalent and \%

Source: Own calculations

\begin{tabular}{|c|c|c|c|c|c|c|c|c|c|c|}
\hline & \multicolumn{2}{|c|}{ Coal } & \multicolumn{2}{|c|}{ Petroleum } & \multicolumn{2}{|c|}{ Crude oil and gas } & \multicolumn{2}{|c|}{ Renewables } & \multicolumn{2}{|c|}{ Total } \\
\hline & Gg & $\%$ & Gg & $\%$ & $\mathrm{Gg}$ & $\%$ & $\mathrm{Gg}$ & $\%$ & $\mathrm{Gg}$ & $\%$ \\
\hline Irrigated field & 86 & 0.0 & 818 & 1.5 & 0 & 0.0 & 0 & 0.0 & 904 & 0.3 \\
\hline Dry field & 290 & 0.1 & 2746 & 5.1 & 0 & 0.0 & 0 & 0.0 & 3036 & 0.9 \\
\hline Irrigated horticulture & 0 & 0.0 & 1049 & 2.0 & 0 & 0.0 & 0 & 0.0 & 1050 & 0.3 \\
\hline Dry horticulture & 0 & 0.0 & 283 & 0.5 & 0 & 0.0 & 0 & 0.0 & 283 & 0.1 \\
\hline Livestock & 0 & 0.0 & 1292 & 2.4 & 0 & 0.0 & 0 & 0.0 & 1292 & 0.4 \\
\hline Forestry & 0 & 0.0 & 0 & 0.0 & 0 & 0.0 & 0 & 0.0 & 0 & 0.0 \\
\hline Other agriculture & 5 & 0.0 & 662 & 1.2 & 0 & 0.0 & 0 & 0.0 & 666 & 0.2 \\
\hline Coal & 22 & 0.0 & 940 & 1.7 & 3 & 0.0 & 0 & 0.0 & 965 & 0.3 \\
\hline Gold & 477 & 0.2 & 673 & 1.3 & 7 & 0.1 & 0 & 0.0 & 1157 & 0.3 \\
\hline Crude, pet. \& gas & 0 & 0.0 & 274 & 0.5 & 11 & 0.1 & 0 & 0.0 & 285 & 0.1 \\
\hline Other mining & 2636 & 1.0 & 1083 & 2.0 & 7 & 0.1 & 0 & 0.0 & 3726 & 1.1 \\
\hline Food & 0 & 0.0 & 0 & 0.0 & 64 & 0.5 & 0 & 0.0 & 64 & 0.0 \\
\hline Textiles & 0 & 0.0 & 0 & 0.0 & 1 & 0.0 & 0 & 0.0 & 1 & 0.0 \\
\hline Footwear & 0 & 0.0 & 29 & 0.1 & 0 & 0.0 & 0 & 0.0 & 29 & 0.0 \\
\hline Other chemical \& rubber & 463 & 0.2 & 0 & 0.0 & 834 & 6.9 & 0 & 0.0 & 1297 & 0.4 \\
\hline Petroleum refineries & 53704 & 20.4 & 0 & 0.0 & 7286 & 60.1 & 0 & 0.0 & 60990 & 17.3 \\
\hline Other non-metal. minerals & 2603 & 1.0 & 0 & 0.0 & 353 & 2.9 & 0 & 0.0 & 2955 & 0.8 \\
\hline Iron \& steel & 14080 & 5.3 & 0 & 0.0 & 3295 & 27.2 & 0 & 0.0 & 17376 & 4.9 \\
\hline Non-ferrous metals & 0 & 0.0 & 0 & 0.0 & 53 & 0.4 & 0 & 0.0 & 53 & 0.0 \\
\hline Other metal products & 6859 & 2.6 & 1192 & 2.2 & 0 & 0.0 & 0 & 0.0 & 8052 & 2.3 \\
\hline Other machinery & 0 & 0.0 & 0 & 0.0 & 34 & 0.3 & 0 & 0.0 & 34 & 0.0 \\
\hline Electrical machinery & 0 & 0.0 & 1087 & 2.0 & 0 & 0.0 & 0 & 0.0 & 1087 & 0.3 \\
\hline Radio & 0 & 0.0 & 148 & 0.3 & 0 & 0.0 & 0 & 0.0 & 148 & 0.0 \\
\hline Transport equipment & 0 & 0.0 & 0 & 0.0 & 6 & 0.0 & 0 & 0.0 & 6 & 0.0 \\
\hline Wood, pulp \& paper & 0 & 0.0 & 0 & 0.0 & 30 & 0.2 & 0 & 0.0 & 30 & 0.0 \\
\hline Other manufacturing & 2857 & 1.1 & 735 & 1.4 & 140 & 1.2 & 0 & 0.0 & 3732 & 1.1 \\
\hline Electricity & 173802 & 65.9 & 0 & 0.0 & 0 & 0.0 & 4608 & 19.8 & 178409 & 50.6 \\
\hline Water & 814 & 0.3 & 2 & 0.0 & 0 & 0.0 & 0 & 0.0 & 816 & 0.2 \\
\hline Construction & 1 & 0.0 & 1575 & 2.9 & 0 & 0.0 & 0 & 0.0 & 1576 & 0.4 \\
\hline Trade & 37 & 0.0 & 32291 & 60.1 & 1 & 0.0 & 0 & 0.0 & 32329 & 9.2 \\
\hline Hotels & 68 & 0.0 & 2 & 0.0 & 0 & 0.0 & 0 & 0.0 & 69 & 0.0 \\
\hline Transport services & 108 & 0.0 & 3785 & 7.0 & 4 & 0.0 & 0 & 0.0 & 3898 & 1.1 \\
\hline Communication & 0 & 0.0 & 18 & 0.0 & 0 & 0.0 & 0 & 0.0 & 18 & 0.0 \\
\hline Financial institutions & 0 & 0.0 & 8 & 0.0 & 0 & 0.0 & 0 & 0.0 & 8 & 0.0 \\
\hline Real estate & 0 & 0.0 & 13 & 0.0 & 1 & 0.0 & 0 & 0.0 & 14 & 0.0 \\
\hline Business activities & 0 & 0.0 & 9 & 0.0 & 0 & 0.0 & 0 & 0.0 & 9 & 0.0 \\
\hline General government & 580 & 0.2 & 1032 & 1.9 & 1 & 0.0 & 0 & 0.0 & 1613 & 0.5 \\
\hline Health sector & 357 & 0.1 & 16 & 0.0 & 0 & 0.0 & 0 & 0.0 & 372 & 0.1 \\
\hline Other service activities & 32 & 0.0 & 4 & 0.0 & 0 & 0.0 & 0 & 0.0 & 36 & 0.0 \\
\hline Residential & 3904 & 1.5 & 1979 & 3.7 & 0 & 0.0 & 18666 & 80.2 & 24549 & 7.0 \\
\hline Total & 263783 & 100.0 & 53744 & 100.0 & 12132 & 100.0 & 23274 & 100.0 & 352932 & 100.0 \\
\hline
\end{tabular}


Table 11: Selected key ratios concerning greenhouse gas emissions and welfare levels: a country comparison with world averages

Source: Winkler et al. (2001)

\begin{tabular}{|c|c|c|c|c|c|c|c|c|}
\hline \multirow[t]{2}{*}{ Key characteristic } & \multirow[t]{2}{*}{ South Africa } & \multirow[t]{2}{*}{ Argentina } & \multirow[t]{2}{*}{ China } & \multirow[t]{2}{*}{ India } & \multirow[t]{2}{*}{ Nigeria } & \multirow[t]{2}{*}{ Brazil } & \multicolumn{2}{|c|}{ World average } \\
\hline & & & & & & & Value & Units \\
\hline \multicolumn{9}{|l|}{ Share of world (\%) } \\
\hline $\begin{array}{l}\text { Total } \mathrm{CO}_{2} \text { emissions } \\
\text { per year (1995) }\end{array}$ & $1.37 \%$ & $0.58 \%$ & $14.30 \%$ & $4.07 \%$ & $0.41 \%$ & $1.12 \%$ & 6,098 & $\begin{array}{l}\text { Million tons } \\
\text { carbon }\end{array}$ \\
\hline $\begin{array}{l}\mathrm{CO}_{2} \text { emissions cumu- } \\
\text { lative (1915-1995) }\end{array}$ & $-1.14 \%$ & $0.50 \%$ & $6.70 \%$ & $1.95 \%$ & $0.23 \%$ & $0.69 \%$ & 227440 & $\begin{array}{l}\text { Million tons } \\
\text { carbon }\end{array}$ \\
\hline Population & $0.73 \%$ & $0.61 \%$ & $21.49 \%$ & $16.11 \%$ & $1.97 \%$ & $2.74 \%$ & 5684.78 & Millions \\
\hline Total GDP for 1995 & $0.57 \%$ & $0.78 \%$ & $9.58 \%$ & $3.43 \%$ & $0.39 \%$ & $2.26 \%$ & 37877689 & $\begin{array}{l}\text { Millions } 1995 \\
\text { Int\$ - PPP }\end{array}$ \\
\hline \multicolumn{9}{|c|}{ Relative to world average $(100 \%)$} \\
\hline GDP per capita & $79 \%$ & $127 \%$ & $45 \%$ & $21 \%$ & $20 \%$ & $83 \%$ & 6,663 & 1995 \$ per year \\
\hline $\begin{array}{l}\text { Emissions intensity } \\
\left(\mathrm{CO}_{2} \text { per } \mathrm{GDP}\right)\end{array}$ & $240 \%$ & $75 \%$ & $149 \%$ & $119 \%$ & $105 \%$ & $49 \%$ & 0.16 & $\begin{array}{l}\mathrm{kg} \text { of } \mathrm{C} / \$ \text { of } \\
\mathrm{GDP}\end{array}$ \\
\hline Emissions per capita & $189 \%$ & $95 \%$ & $67 \%$ & $25 \%$ & $21 \%$ & $41 \%$ & 1.07 & $\begin{array}{l}\text { tons of } C \text { per } \\
\text { person }\end{array}$ \\
\hline
\end{tabular}

Two questions now need to be asked. Firstly, are these numbers important? Secondly, what is the extent of this importance? The answer to the former should be yes when compared to other countries. According to Winkler et al. (2001), South Africa's emissions intensity is about 240 per cent above world average, and the highest of the developing countries considered (see Table 11). In 1995, the country's emissions intensity was $2.82 \mathrm{~kg} \mathrm{CO}$ per purchase power parity adjusted to $1990 \$$ of GDP produced, compared to a world average of 0.87 and a non-OECD average of 1.99. In terms of emissions per capita, South Africa is 189 per cent above the world average of 1.07 tons of carbon per person. This compares extremely unfavourably with that of Argentina (95 per cent of world average), and China's 67 per cent, India's 25 per cent, Nigeria's 21 per cent and Brazil's 41 per cent. Though these are populous countries, they do represent countries of a comparable state of development. These high energy intensities suggest that South Africa has limited scope to increase its emissions at a rate faster that the country's GDP. It also suggests that policies that are custom-made to improve GDP, reduce carbon emissions but also alleviate poverty are much needed.

\section{Concluding remarks}

A greenhouse gas emissions inventory has been constructed, based on the energy balance of South Africa and various emission factors. The sectoral dimensions of the inventory reconcile to those of the 1998 social accounting matrix of South Africa. This enables the economic analyst to model various policies using a variety of applied modelling techniques.

Based on the information contained in the inventory, greenhouse gas emissions from combustion sources amounted to $352932 \mathrm{Gg}$ in 1998, with the electricity generation sector contributing 178 $409 \mathrm{Gg}$ or almost 51 per cent, followed by the petroleum refineries which contributed $60990 \mathrm{Gg}$ or 17.3 per cent of the total. It has also been indicated that these values are significant in a global context relative to other developing countries. This necessitates the use of economic modelling techniques in the search for the optimum policy scenario in an effort to reduce the country's carbon footprint.

\section{Acknowledgements}

The data collection and analysis was funded by the Poverty Reduction and Environmental Management (PREM) Programme, which is fully funded by the Ministry of Foreign Affairs, the Netherlands. The authors are grateful to Prof. Richard Tol, Prof. Jan van Heerden, Dr Reyer Gerlagh and two anonymous referees for comments received on earlier drafts, remaining errors are, however, that of the authors.

\section{Disclaimer}

Views expressed in this paper are those of the authors, and do not necessarily reflect those of any institution they may be involved with. 


\section{References}

Blignaut, J.N and King, N.A. 2002. The externality cost of coal combustion in South Africa. Bridging the Economics/ Environment divide conference proceedings. ISBN 1-86854-437-0. Pretoria: Forum for Economic and Environment.

Blignaut, J.N. and Zunckel, M. 2004. The cost of a decline in air quality. In: Blignaut, J.N. and De Wit, M. (eds.) Sustainable Options. Cape Town: UCT Press.

Clement, K. and Foster, S. 2000. An investigation into mining as an energy and water using sector and its environmental impacts. Report by DBSA for GTZfunded project WWF Macro Economic Reforms and Sustainable Development in Southern Africa.

Department of Minerals and Energy (DME). 2000. Energy balance for South Africa: 1998. Pretoria: DME.

Eskom, 2000. Annual Report 2000. Internet: http://www.eskom.co.za/annreport01/ Accessed May 2004.

Foster, S. 1998. A South African national economic and environmental policy frame-work, Development Southern Africa, 15(2).

Freeman, P.N.W., Naude, C.M., Pretorius, J., Coovadia, T., Matjila, S.M. 2000. The Transport Sector-Energy Use and Environmental Impacts. Report by DBSA for GTZ-funded project WWF Macro Economic Reforms and Sustainable Development in Southern Africa.

Gaffen, M., Naude, C., Lombaard, P., Maasdorp, G., Taylor, A. and Pretorius, J. 2000. A Quantitative analysis of full cost associated with motor vehicle use in South Africa. Report for Department of Transport, funded by USAID as well as Moving South Africa: An action Strategy.

Howells, M.I. and Solomon, M. 2000. South African Greenhouse Gas energy emissions inventory for the year 1994. Journal of Energy in South Africa, 11(4): 272-278.

IPCC (Intergovernmental Panel on Climate Change). 1996. IPCC Guidelines for National Greenhouse Gas Inventories: Reference Manual, Volume 3, United Nations Environment Program, the Organisation for the Co-operation and Development, the International Energy Agency and the Intergovernmental Panel on Climate Change, Cambridge University Press, United Kingdom.

Lloyd, P., Rukato, H. and Swanepoel, R. 2000. Liquid fuels production. Report by DBSA for GTZ- funded project WWF Macro Economic Reforms and Sustainable Development in Southern Africa.

Pinheiro, H.J., Boshoff, H.P. And Pretorius, C.C. 1997. Analysis of coal product samples of producing South African collieries. Pretoria: CSIR.

RSA (Republic of South Africa) 2000. South Africa: Initial National Communication under the United Nations Framework Convention on Climate Change, Pretoria, Department of Environmental Affairs and Tourism.

Spalding-Fecher, R., Matibe, D., Okese, Y., Eberhart, R. and Davis, M. 2000. Electricity production and the environment. Report by DBSA for GTZ- funded project WWF Macro Economic Reforms and Sustainable
Development in Southern Africa.

Trollip, H. 1996. Overview of the South African energy sector. Pretoria, Dept of Minerals \& Energy, Chief Directorate: Energy.

UNFCCC (United Nations Framework Convention on Climate Change). 1999. Conference of the Parties, Fourth Session, Buenos Aires, 2-13 November 1998, Item $4(\mathrm{a})(\mathrm{i})$ of the provisional agenda, FCCC/ CP/1998/11/Add.2 (www.unfccc.de/resource/docs/ cop4/11a02.pdf).

Trikam, A. 2002. Greenhouse gas mitigation options in the industrial sector. South African Journal of Economic and Management Sciences, 5(2):473-498.

Visser, M., Spalding-Fecher, R. and Leiman, A. 2000. Manufacturing and economic growth. Report by DBSA for GTZ- funded project WWF Macro Economic Reforms and Sustainable Development in Southern Africa.

Winkler, H., Tyani, L., and Spalding-Fecher R. 2001. What could future carbon emission allocation schemes and targets mean for South Africa? Energy and Development Research Centre (EDRC), University of Cape Town, South Africa.

Received 2 March 2005; revised 19 July 2004 